\title{
The winter pack-ice zone provides a sheltered but food-poor habitat for larval Antarctic krill
}

\author{
Bettina Meyer ${ }^{1,2,3 \star}$, Ulrich Freier, ${ }^{1,4}$, Volker Grimm ${ }^{5}$, Jürgen Groeneveld ${ }^{6}$, Brian P. V. Hunt ${ }^{7,8,9}$, \\ Sven Kerwath ${ }^{10,11,12}$, Rob King ${ }^{13}$, Christine Klaas', Evgeny Pakhomov ${ }^{7,9}$, Klaus M. Meiners ${ }^{13,14}$, \\ Jessica Melbourne-Thomas ${ }^{13,14}$, Eugene J. Murphy ${ }^{15}$, Sally E. Thorpe ${ }^{15}$, Sharon Stammerjohn ${ }^{16}$, \\ Dieter Wolf-Gladrow 17, Lutz Auerswald ${ }^{10,12}$, Albrecht Götz ${ }^{18,19,20}$, Laura Halbach ${ }^{11}$, Simon Jarman ${ }^{13,21}$, \\ So Kawaguchi ${ }^{13,14}$, Thomas Krumpen ${ }^{22}$, Gernot Nehrke ${ }^{17}$, Robert Ricker ${ }^{22}$, Michael Sumner ${ }^{13,14}$, \\ Mathias Teschke', Rowan Trebilco ${ }^{14}$ and Noyan I. Yilmaz $\mathbb{D}^{23}$
}

\begin{abstract}
A dominant Antarctic ecological paradigm suggests that winter sea ice is generally the main feeding ground for krill larvae. Observations from our winter cruise to the southwest Atlantic sector of the Southern Ocean contradict this view and present the first evidence that the pack-ice zone is a food-poor habitat for larval development. In contrast, the more open marginal ice zone provides a more favourable food environment for high larval krill growth rates. We found that complex under-ice habitats are, however, vital for larval krill when water column productivity is limited by light, by providing structures that offer protection from predators and to collect organic material released from the ice. The larvae feed on this sparse ice-associated food during the day. After sunset, they migrate into the water below the ice (upper $20 \mathrm{~m}$ ) and drift away from the ice areas where they have previously fed. Model analyses indicate that this behaviour increases both food uptake in a patchy food environment and the likelihood of overwinter transport to areas where feeding conditions are more favourable in spring.
\end{abstract}

\begin{abstract}
$\Lambda$ ntarctic krill Euphausia superba, a key species in Southern Ocean food webs ${ }^{1}$, plays a central role in ecosystem processes and community dynamics of apex predators, and is the target of a commercial fishery ${ }^{2}$. Krill spawn in late spring and their larvae develop during summer, autumn and under the ice in winter to emerge as juveniles in the following spring. The newly spawned eggs sink from the surface to up to $1,000 \mathrm{~m}$ depth where they hatch and the developing larvae actively swim upwards to feed in the upper water column ${ }^{1}$. Larval Antarctic krill have low lipid reserves, which are insufficient to support long periods of starvation. Therefore, winter, when primary production is minimal, is assumed to be a critical bottleneck for larval krill development and hence recruitment to the adult population ${ }^{3,4}$. Present hypotheses suggest that high algal biomass in winter sea ice enhances larval krill winter-feeding conditions and growth ${ }^{5-8}$. This implies that larvae
\end{abstract}

have access to this high algal biomass within the sea ice. However, recent observations ${ }^{9,10}$ indicate that the linkage between sea ice and krill recruitment success is not as direct as has been suggested. The timing of ice-edge advance and annual ice-season duration is highly variable, and does not necessarily show a clear link to krill recruitment in the following year (Supplementary Figs. 1 and 2). Along the Antarctic Peninsula, adult krill have a five to six year population cycle with oscillations in biomass exceeding an order of magnitude ${ }^{9}$. According to bioenergetics models, part of the variability is due to interannual variation in reproductive output ${ }^{11}$ as well as autumn blooms that may govern the possible overwinter survival rate of larvae $e^{11,12}$. In the Bransfield Strait, three krill winter surveys have shown that krill abundance is an order of magnitude higher than in summer, regardless of concurrent sea-ice conditions ${ }^{10}$. Furthermore, although algal concentrations within sea ice can be

'Department of Biosiences, Alfred Wegener Institute, Helmholtz Centre for Polar and Marine Research, Section Polar Biological Oceanography, Bremerhaven, Germany. ${ }^{2}$ Institute for Chemistry and Biology of the Marine Environment, Carl von Ossietzky University Oldenburg, Oldenburg, Germany. ${ }^{3} \mathrm{Helmholtz}$ Institute for Functional Marine Biodiversity at the University of Oldenburg, Oldenburg, Germany. ${ }^{4}$ SC-Scientific Consulting, Neuss, Germany. ${ }^{5}$ Department of Ecological Modelling, Helmholtz Centre for Environmental Research-UFZ, Leipzig, Germany. ${ }^{6}$ Institute of Forest Growth and Computer Science, Technische Universität Dresden, Tharandt, Germany. ${ }^{7}$ Department of Earth and Ocean and Atmospheric Sciences, University of British Columbia, Vancouver, British Columbia, Canada. ${ }^{8}$ Hakai Institute, Heriot Bay, British Columbia, Canada. ${ }^{9}$ Institute for the Oceans and Fisheries, University of British Columbia, Vancouver, British Columbia, Canada. ${ }^{10}$ Department of Agriculture, Forestry and Fisheries, Fisheries Research and Development, Cape Town, South Africa. "Department of Biological Sciences, University of Cape Town, Rondebosch, South Africa. ${ }^{12}$ Department of Animal Sciences, Stellenbosch University, Stellenbosch, South Africa. ${ }^{13}$ Department of the Environment and Energy, Australian Antarctic Division, Kingston, Tasmania, Australia. ${ }^{14}$ Antarctic Climate and Ecosystems Cooperative Research Centre, University of Tasmania, Hobart, Tasmania, Australia. ${ }^{15}$ British Antarctic Survey, Natural Environment Research Council, Cambridge, UK. ${ }^{16}$ Institute of Arctic and Alpine Research, University of Colorado, Boulder, CO, USA. ${ }^{17}$ Department of Biosiences, Alfred Wegener Institute, Helmholtz Centre for Polar and Marine Research, Section Marine BioGeoScience, Bremerhaven, Germany. ${ }^{18}$ South African Environmental Observation Network, Elwandle Node, Grahamstown, South Africa. ${ }^{19}$ Department of Ichthyology and Fisheries Science, Rhodes University, Grahamstown, South Africa. ${ }^{20}$ Zoology Department, Nelson Mandela Metropolitan University, Port Elizabeth, South Africa. ${ }^{21}$ Trace and Environmental DNA (TrEnD) Laboratory, Department of Environment and Agriculture, Curtin University, Bentley, Western Australia, Australia. ${ }^{22}$ Department Climate Sciences, Alfred Wegener Institute, Helmholtz Centre for Polar and Marine Research, Section Sea Ice Physics, Bremerhaven, Germany. ${ }^{23}$ Institute of Marine Sciences and Management, Istanbul University, Istanbul, Turkey. ${ }^{\star}$ e-mail: bettina.meyer@awi.de 
substantially higher than in the water column directly beneath this sea ice, they are also highly variable, ranging by a factor of 60 (ref. ${ }^{13}$ ). The slow growth of larvae during winter, until at least September, observed in different regions of the Southern Ocean ${ }^{6,8,14,15}$, suggests that the potential dietary source in the sea ice is not readily accessible to larval krill (Supplementary Table 1).

To determine the mechanistic linkage between larval krill-ice interactions, we undertook a comprehensive study of the behaviour and biology of larval krill in relation to under-ice habitat types in the northern Weddell Sea during late winter 2013, from the German icebreaker RV Polarstern. We applied an integrated, multi-analytical approach to observe and sample larval krill in relation to high- and low-structured sea-ice regions across multiple spatial scales, spanning metres to kilometres. We undertook a suite of analyses of krill and their habitats at a series of sites, from open water to the packice zone, including direct under-ice observations and quantitative estimates of the krill larval distribution under sea ice. The results of these field studies were incorporated into models to better understand larval krill-sea ice interactions over short timescales (foraging model), seasonal and annual timescales (advection model) and on decadal timescales (sea-ice model). If sea ice is indeed critical to survival for larval krill, then climate-driven sea-ice changes should greatly affect the future of krill in the Southern Ocean ecosystem. This knowledge is crucial to enable predictions of the response of krill stocks to climate change ${ }^{3,4}$.

\section{Results}

Our survey across open water, the marginal ice zone and the packice zone (Fig. 1) showed that krill larvae were abundant in the highly deformed and thicker sea-ice regions in both the pack-ice and the marginal ice zone (ice type 1, Fig. 2a,b and Supplementary Table 2). In these regions, dive observations demonstrated that the larval distribution was patchy and the larval density varied by several orders of magnitude from a few to thousands per square metre (Fig. 3, mean of 853 larvae $\mathrm{m}^{-2}$, Supplementary Videos 1 and 2). Horizontal net tows and dive observations demonstrated that larvae were almost

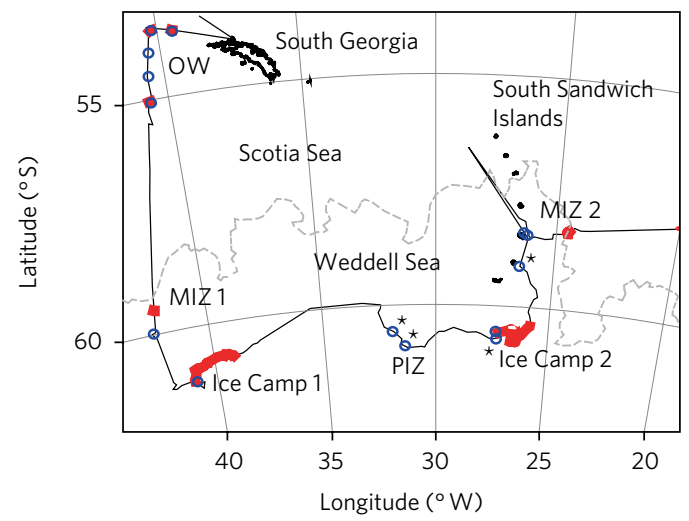

Fig. 1 | Cruise track with larval krill sampling stations. The solid line is the cruise track. Red denotes stations where larvae were caught for analyses of growth rate, feeding activity and stomach content. The dashed grey line shows maximum sea-ice extent. Blue circles are stations where larval krill abundance was estimated with the RMT 1+8 during night, when larvae are in the water column and not associated with the sea ice (for detail see main text). In the pack-ice region, blue circles with an asterisk indicate lessdeformed sea-ice regions (ice type 2 ), whereas the remaining RMT stations were in highly deformed sea-ice areas (ice type 1). For the definition of sea-ice types see Fig. 2, the associated text and Methods, and for details of sampling see Methods. OW, ice-free waters in winter; MIZ, marginal ice zone; PIZ, pack-ice zone. absent under less-deformed or smooth ice (ice type 2, Fig. 2c and Supplementary Table 2). In highly deformed sea-ice regions, the largest daytime larval densities (up to 5,000 larvae $\mathrm{m}^{-2}$ ) were found on upward-facing ice ledges ('terraces', Fig. 3 and Supplementary Video 3) between 1 and $2 \mathrm{~m}$ depth below the surface.

Feeding and growth followed the food availability, in terms of chlorophyll (chl) $a$ (Fig. 4a) and particulate organic matter concentration (Supplementary Fig. 3) in the water column, with highest values in the marginal ice zone (Fig. $4 a-c$ ). Larval growth rates correlated positively with food availability in the mixed layer of the water column (Fig. 4d) but not with sea-ice algae biomass (Fig. 4e). Larvae consistently exhibited the lowest growth rates (by up to a factor of four) in the pack-ice zone (Fig. 4c), regardless of sea-ice algae biomass differing significantly between sampling sites in this zone by a factor of two (Fig. 4e). Krill larvae exhibited continuous feeding behaviour on the sea-ice surfaces in the pack-ice zone (Supplementary Videos 3 and 4), but stomachs contained significantly less food than in the open-water region (Supplementary information). The low ingestion rates of larvae in the pack-ice zone suggest that algae in the sea ice were not readily accessible (Supplementary Fig. 4). Stomach content analyses of larvae from the open-water region, the marginal ice zone and the pack-ice zone demonstrate an opportunistic feeding behaviour ranging from an autotrophic to heterotrophic diet and detritus ${ }^{14,15}$ (Supplementary Fig. 5) and underline the highly variable feeding activity of larval krill in the pack-ice region (Fig. 4b). The stomach content and ingestion rates of larvae from Ice Camp 2 during a $24 \mathrm{~h}$ period suggest a diel cycle in feeding (Supplementary Figs. 4 and 6). Our results demonstrate that larval krill are most abundant in highly deformed sea-ice regions in the pack ice and the marginal ice zone and that the rafted sea-ice areas in the marginal ice zone provide the most suitable environment for high larval growth rates.

Krill larvae displayed a distinct diel vertical migration pattern in both the pack-ice zone and the large ice-free regions in the marginal ice zone. During the day, the larvae were found closely associated with the ice, while at sunset they left the ice and dispersed into the upper $20 \mathrm{~m}$ of the water column for the duration of the night (Fig. 4f,g, Supplementary Fig. 7 and Supplementary Videos 3 and 5).

We examined the implications of the larval behaviour and distribution observed during the survey in a series of model studies. We developed a model of larval krill foraging success that incorporates our field observations of the diel vertical migration of larvae associated with differential drift of the sea ice and the ocean (Fig. 4g). We found that the observed reverse diel vertical migration of larvae can enhance foraging success in a patchy, low-food environment (Supplementary Fig. 8).

To examine the implications of our results on the overwinter dispersal of larvae, we undertook a Lagrangian model analysis of the diel vertical migration between the differentially moving ice and upper ocean ${ }^{16,17}$. The advection model indicates the vertical migration is important in determining the overwinter transport pathways and distribution of larvae during late winter. The model predicts that larval krill located under sea ice in April in the northwestern Weddell Sea region (Fig. 5a) are transported into the highly productive marginal ice zone and adjacent open ocean along the South Scotia Ridge by mid-September when undertaking the reverse diel vertical migration (Fig. 5b). This is the area where high concentrations of larvae were observed during our study at the same time of year. The model further shows that these larvae are moved generally towards the Scotia Sea in spring (mid-November, Fig. 5c), with slow transport and enhanced retention around the southern Scotia Arc.

Our results indicate that the deformed ice regions are an important overwintering habitat for larval krill. We developed a model to examine how the distribution and extent of this habitat may be affected by future climate change (Fig. 6a,b). The sea-ice-habitat projection modelling predicts that highly deformed sea-ice regions that 

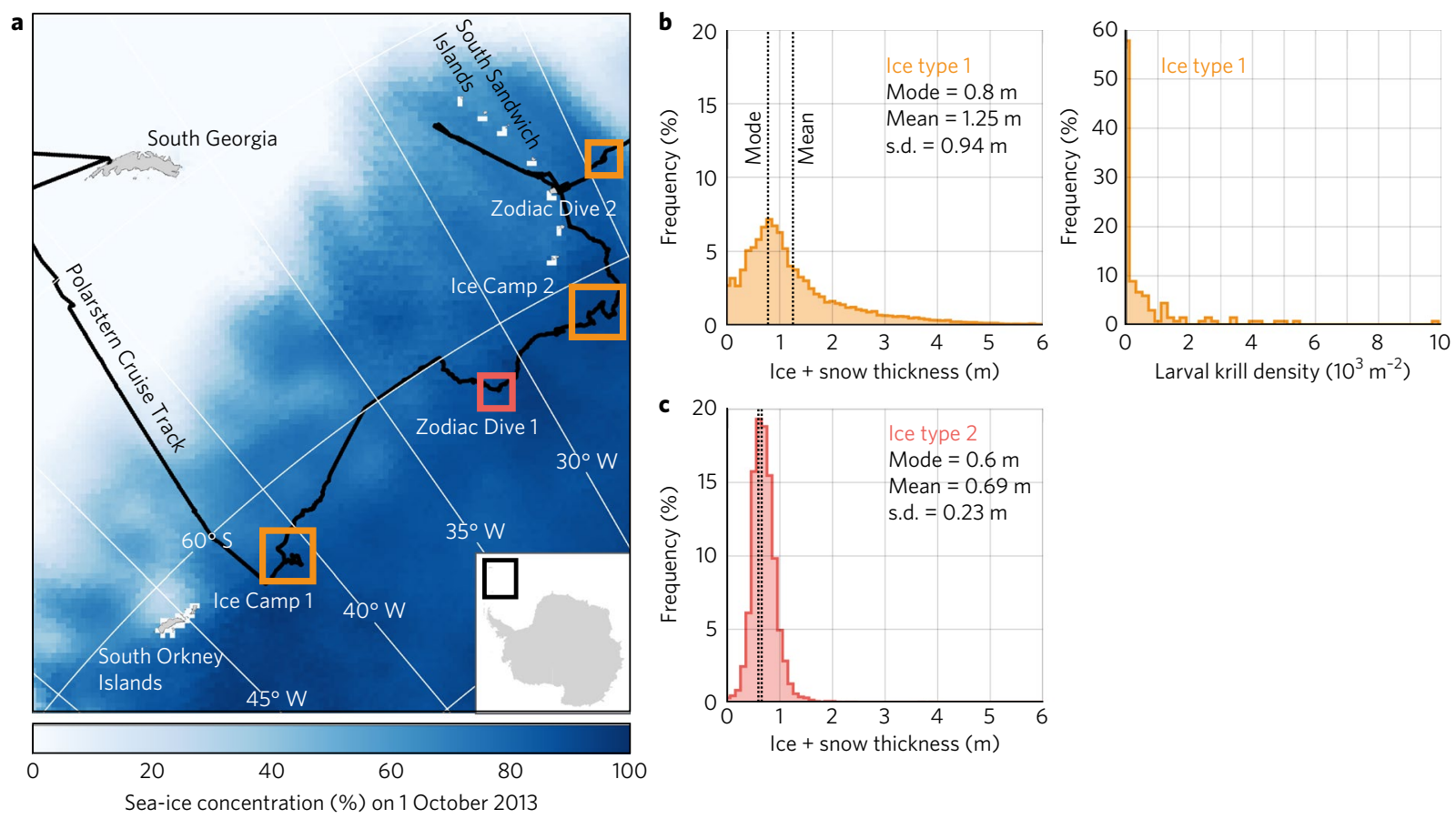

Larval krill density $\left(10^{3} \mathrm{~m}^{-2}\right)$

Fig. 2 | Large-scale sea-ice thickness and degree of ice formation. a, Sea-ice concentration. The squares show stations in highly deformed (orange) and less-deformed (red) sea-ice regions, retrieved from Airborne electromagnetic (AEM)-bird measurements. The sea-ice concentration data (see colour scale) was provided by the University of Bremen. $\mathbf{b}$, Ice and snow thickness of highly deformed sea ice (ice type 1, left) and larval krill density in ice type 1 (right) are shown. c, Un-deformed flat-level ice regions (ice type 2). The ice-type examples shown are from Ice Camp 1 (ice type 1) and the region between Ice Camp 1 and 2 (ice type 2). At dive stations of ice type 2 (for example, Zodiac Dive 1), the diver observed no larval krill associated with the sea ice. The difference between the mean and the modal sea-ice thickness indicates the degree of sea-ice deformation: the higher the difference, the higher the deformation of sea ice.

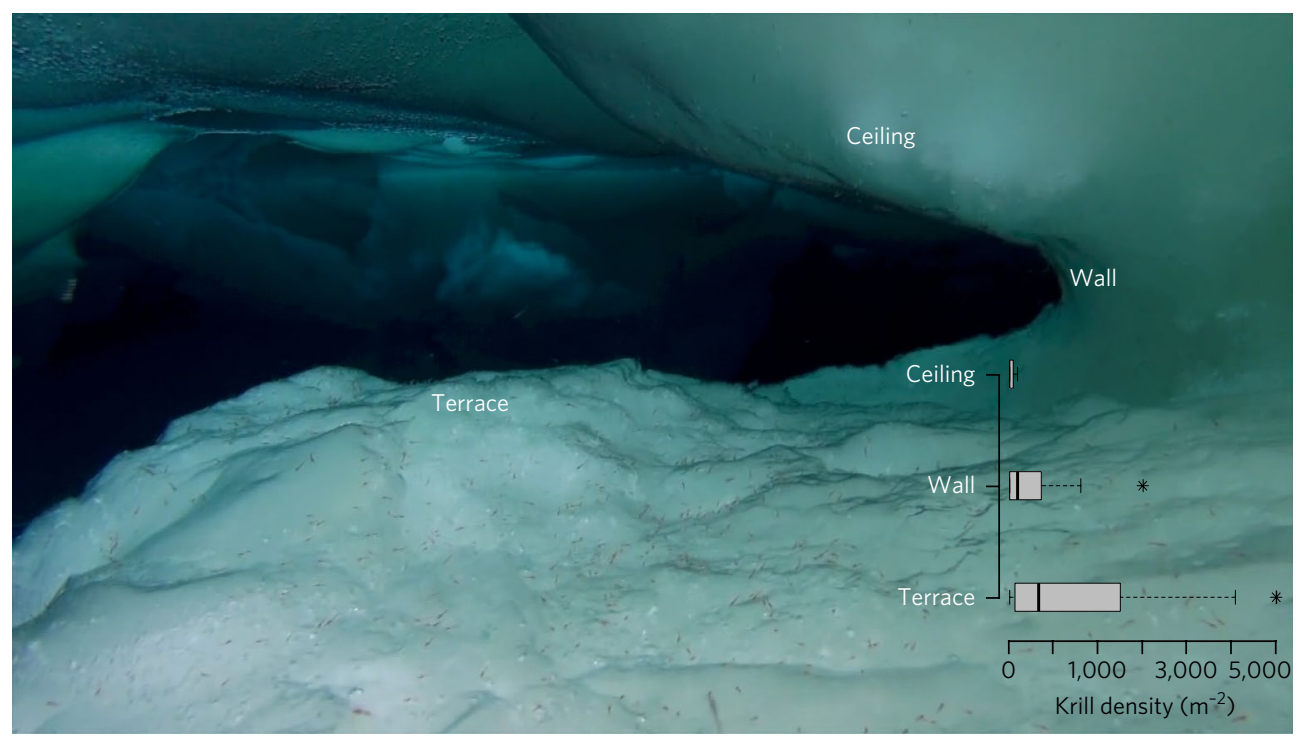

Fig. 3 | Larval krill on a horizontal ice floe. Photograph of krill larvae (red spots) associated with the under-ice habitat. The inset graph shows the density relative to sea-ice sub-surface orientation $\left(n=136,{ }^{\star} P .<0.001\right)$. Boxplots denote median, range and first and third quantiles, see also Supplementary Video 3.

are favourable for larval krill overwintering will become more prevalent in the future under conditions predicted for 2100 (Fig. 6b) ${ }^{18,19}$. At the same time, a southward movement of the marginal ice zone is forecast during this century due to a decline in overall sea-ice extent (Fig. 6b), leading to ice-free conditions in the southern Scotia Sea and northern Weddell Sea during late winter and early spring.

\section{Discussion}

Previous investigations of larval krill overwintering have taken place at various times (early to late winter) and places (western Antarctic Peninsula, northern Weddell Sea, Lazarev Sea, East Antarctica), and focused on individual aspects (larval growth, feeding, metabolic activity, distribution and behaviour under sea ice) either separately 


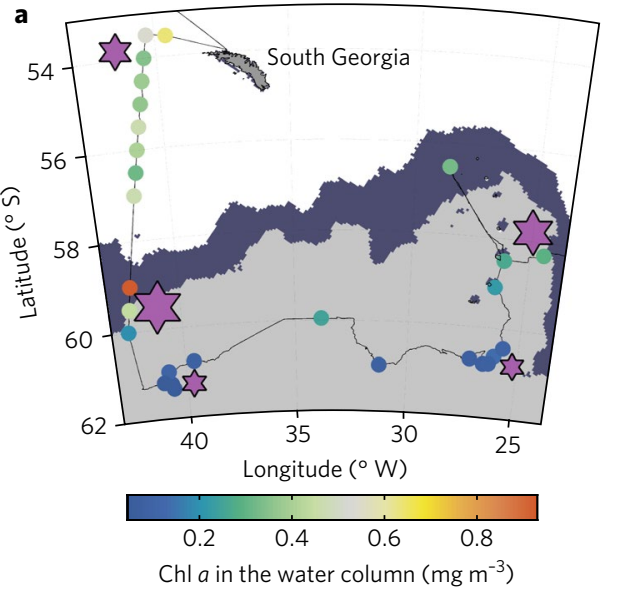

d

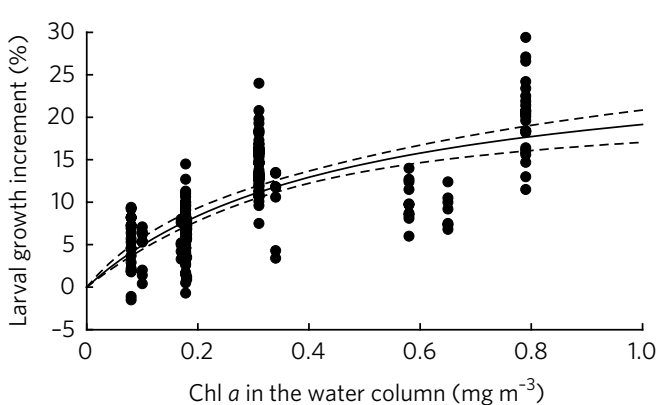

f

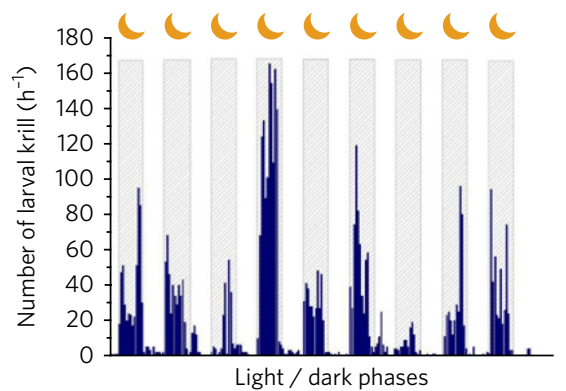

$\mathbf{g}$

20

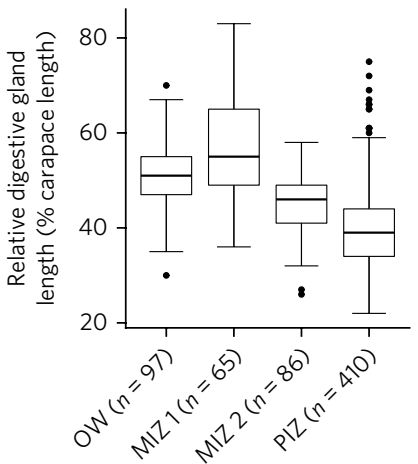

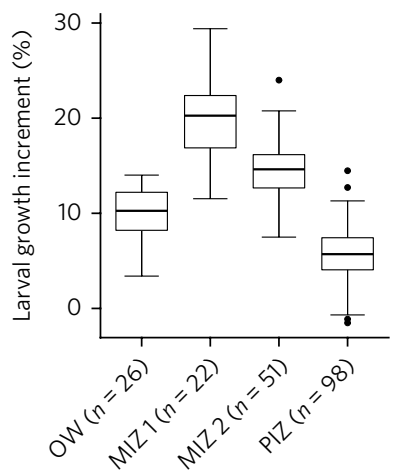

e

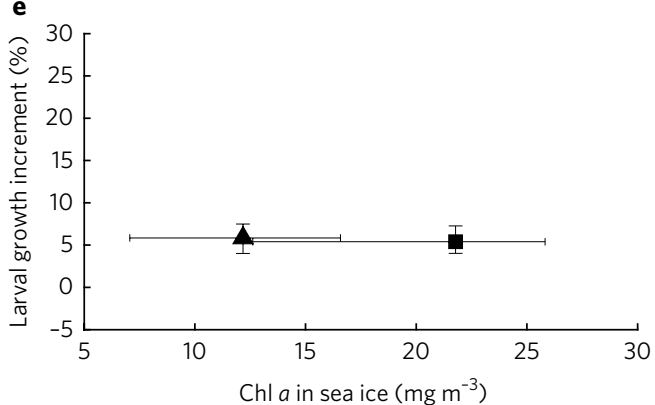

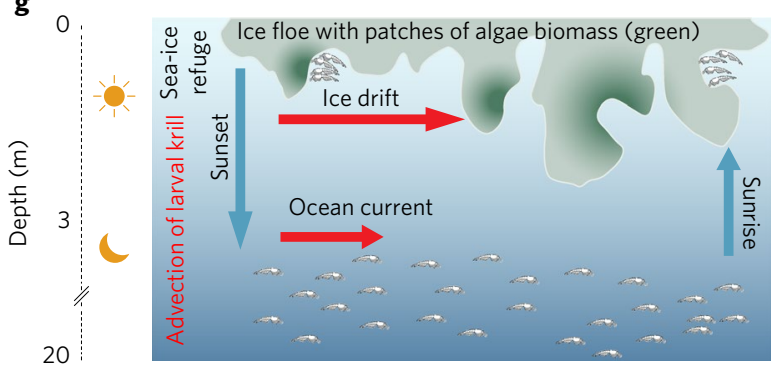

Fig. 4 | Larval krill growth in relation to food supply in the water column and in sea ice, and diel vertical migration behaviour. a, Chl $a$ concentration in the mixed layer of the water column along the cruise track (mixed layer depth was up to $80 \mathrm{~m}$ ). Marginal ice zone indicated by dark blue $(<25 \%$ of sea-ice cover) and pack-ice zone by grey ( $>70 \%$ of sea-ice cover). Purple stars indicate magnitude of larval growth rates at sampling sites. b,c, Feeding activity (relative digestive gland length; b) and larval growth (growth increment in \% per intermoult period; c) at sampling sites. Boxplots denote median, range, first and third quantiles and outliers (1.5 times the interquartile range). For locations of sampling regions see Fig. 1. OW, ice-free waters; MIZ, marginal ice zone; PIZ, pack-ice zone. d, Larval growth in relation to food supply (chl $a$ in the water column). We have fitted a Michaelis-Menten model to the data (larval growth rate $=\mathrm{Vm} \times \mathrm{chl} a /(\mathrm{chl} a+\mathrm{Ks}), \mathrm{Vm}=28.16 \pm 3.06, \mathrm{Ks}=0.47 \pm 0.09)$. Envelope lines are the $95 \%$ confidence intervals for nonlinear models based on uncertainty propagation. $\mathrm{Vm}$ and $\mathrm{Ks}$ are constants representing, respectively, maximum growth and the chl $a$ concentration at which growth is half the maximum. Ks reflects the ability to grow at low food concentrations. e, Larval growth in the pack-ice zone ( $y$ axis) in relation to food supply (mean chl $a$ concentration in sea ice) at Ice Camp 1 (circle, $n=75$ ) and Ice Camp 2 (triangle, $n=84$ ). Growth data are shown as median with maximum and minimum values ( $n=28$ at Ice Camp 1, $n=71$ at Ice Camp 2). f, Number of krill caught every hour during night (grey bars) and during daylight hours (white bars) at $15 \mathrm{~m}$ depth beneath the ship with a pump system. g, Movement pattern of larvae observed by divers. During the day, larvae are patchily distributed and associated with the sea-ice subsurface, whereas during night they are dispersed in the upper $20 \mathrm{~m}$ of the water column and transported due to the differential movement of ocean and ice to another location under the ice the following day. The length of the red arrows indicates the current speed and the blue arrows indicate the reverse diel vertical migration of larvae.

or as combinations of a few, to understand the larval krill-sea ice relationship ${ }^{20}$, making it difficult to get a comprehensive picture of the mechanistic relationship between sea ice and larval krill. Our observations reveal that krill larvae are predominantly found on sea-ice terraces (the floor of over-rafted sea-ice floes) in winter, re-iterating the importance of over-rafting sea ice for creating good habitats ${ }^{14,21}$, and document the reverse diel migration of larvae between the sea ice and near-surface layer of the water column ${ }^{22}$. These findings are all consistent with earlier studies from the West Antarctic Peninsula region $^{6-8,15,21,22}$ and the Lazarev Sea ${ }^{14}$. However, the holistic approach we took to reveal the krill larvae-sea ice interactions shows the adaptive nature of the larval krill behaviour observed and provides a strong indication that our findings reflect the general behaviour of larval krill during winter in the Southern Ocean. 

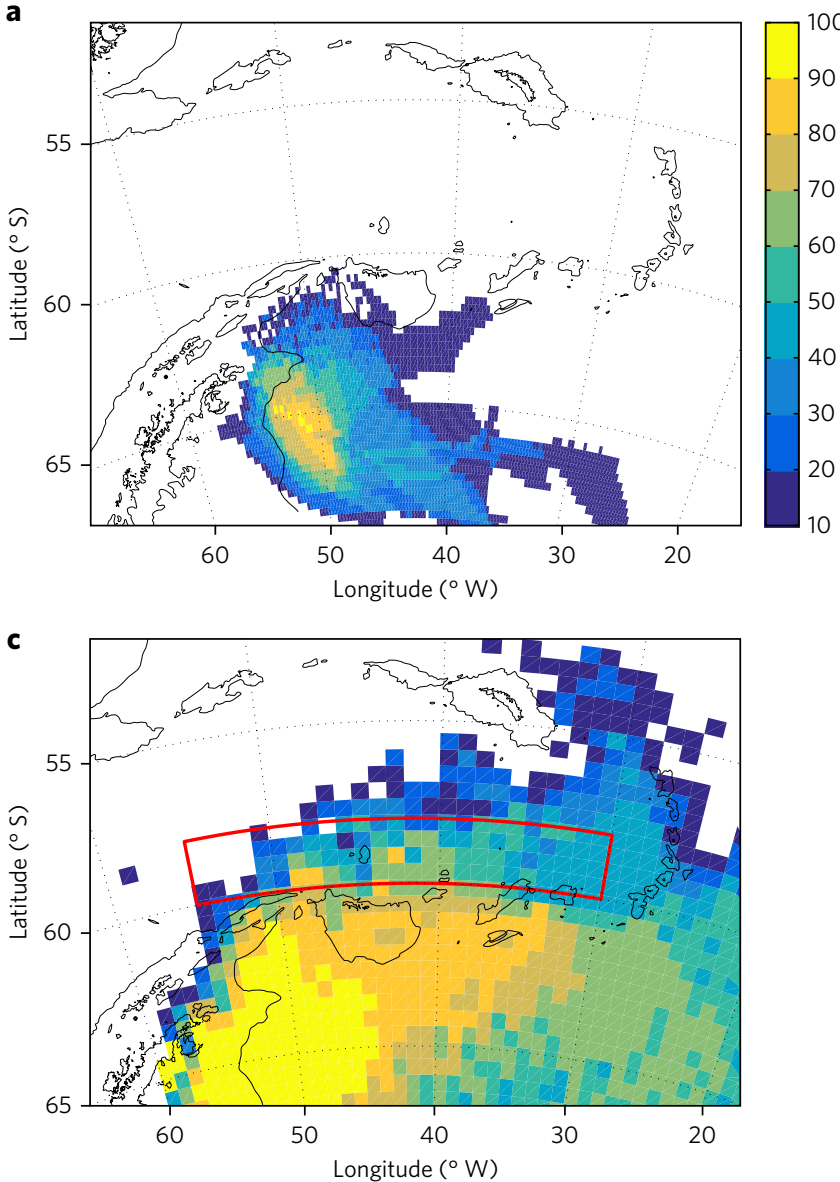

b

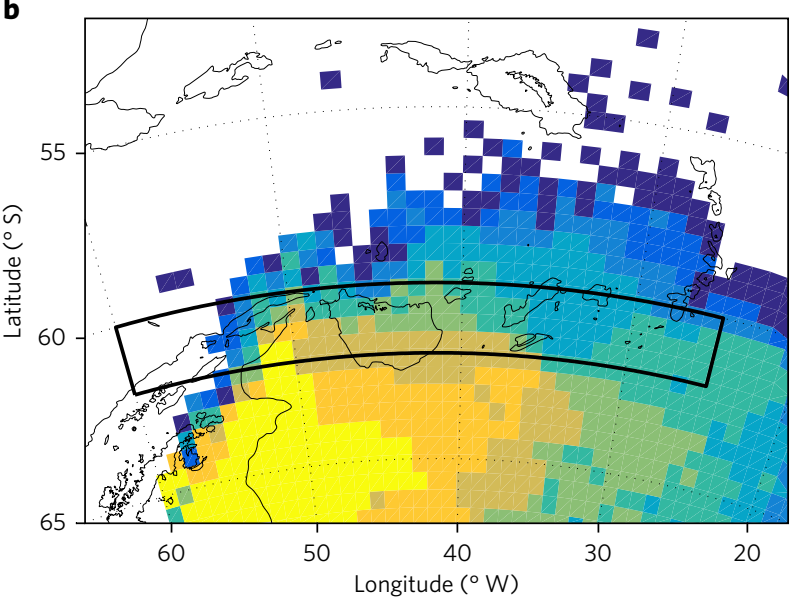

d

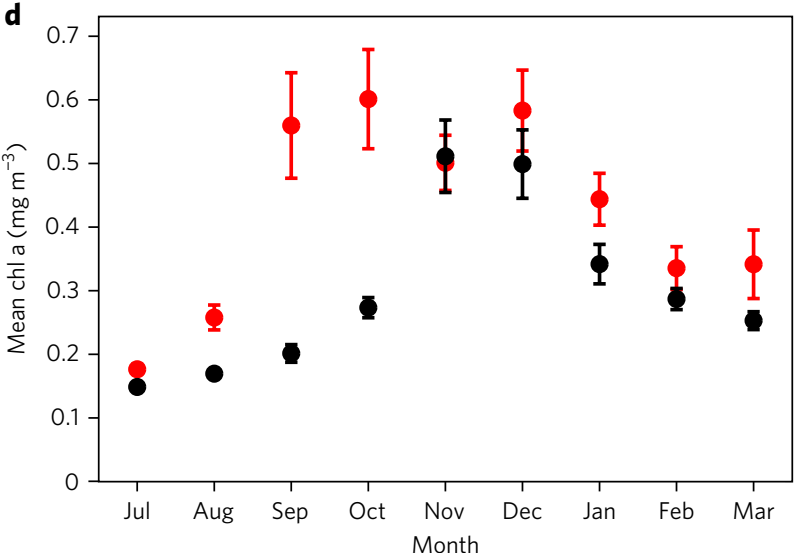

Fig. 5 | Modelled distribution of Antarctic krill larvae and mean chl a concentration for two regions of the Scotia Sea. a, Origin of modelled larvae that are distributed along the South Scotia Ridge (black box in b) in mid-September, assuming vertical migration of the larvae between the sea-ice surface and the near-surface ocean beneath the sea ice. Grid cells are coloured according to frequency of origin (percentage of nine annual model runs; 2005-2013). Larvae were released from all model grid cells with sea-ice cover at the start of April in each of the model runs. $\mathbf{b}$, Frequency of distribution in late winter (mid-September) of all larvae released under sea ice in April, coloured according to a. c, Frequency of distribution in spring (mid-November) of all larvae released under sea ice in April, coloured according to a. d, Mean and standard error of monthly mean Sea-Viewing Wide Field-of-view Sensor (SeaWiFS) $\mathrm{chl}$ a concentration ( $\mathrm{mg}^{-3} ; 9 \mathrm{~km}$ resolution data) for the South Scotia Ridge (black series corresponding to black rectangle in b) and southern Scotia Sea (red series corresponding to red rectangle in c) for the period October 1997 to December 2010. The monthly area averaged data were produced with the Giovanni online data system, developed and maintained by the NASA. Goddard Earth Sciences Data and Information Services Center (GES DISC). Calculations were undertaken using Matlab R2013a.

Our observations and data provide a new perspective on the relationship between krill larvae and winter sea ice. In contrast to the present hypothesis that sea ice acts primarily as a feeding ground for overwintering larvae, we suggest that the pack-ice zone is actually a food-poor habitat that allows larvae to only maintain a positive metabolic balance with slow growth rates ${ }^{14,15}$. During winter, the larvae feed on food particles released from the ice or associated with $\mathrm{it}^{14}$ but not directly on the algae communities growing on or in the ice as has previously been suggested ${ }^{5-7}$.

Concentrations of chl $a$ within the sea ice and water column in the pack-ice zone found during our study were consistent with previous data from the Weddell Sea and other regions of the Southern Ocean in winter (western Antarctic Peninsula region, northwestern Weddell Sea, Lazarev Sea, East Antarctica) $)^{8,13-15,23-26}$. Previous larval krill winter studies in the western Antarctic Peninsula region demonstrate significantly different growth rates between years, at the same time and location, due to variable chl $a$ concentration in the water column. In addition, they show that overall growth in mid-winter is much lower than in autumn (April-May) and late winter-early spring (after mid-September $)^{6-8}$. Both findings are in good agreement with our results, highlighting food-poor conditions under winter sea ice and that larval growth during winter depends on the accessibility of organic material in the waters underlying the ice as a food source for the larvae.

Our study indicates that it is not the sea-ice extent per se, as previously thought, but the availability of regions of highly deformed sea-ice regions that matters for the survival of larvae in winter. Krill larvae can cope with a limited food supply under winter pack ice through a variety of mechanisms, ranging from shrinking in size ${ }^{6,8}$, undergoing indirect developmental pathways ${ }^{14,15}$, reducing metabolic rates $^{14}$ and switching from an autotrophic to heterotrophic diet ${ }^{14,15}$. The evolution of these strategies indicates that food availability is generally unreliable and typically low in the pack-ice region. The upward-facing ice ledges (sea-ice terraces) in the deformed sea-ice regions act as collection surfaces for organic material released from the ice, thereby making it an available food source for the larvae ${ }^{14}$.

In contrast to the pack-ice region, the marginal ice zone provides favourable feeding conditions due to light, nutrients and the grinding of the ice floes, due to the physical proximity of the open ocean (for example, waves), and the beneficial highly deformed sea-ice habitats. These combined factors facilitate high larval krill growth rates in areas protected from predation. 
Current

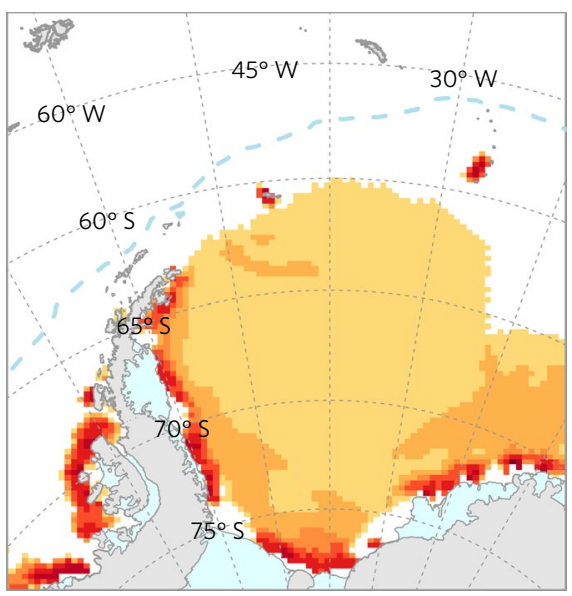

Warm

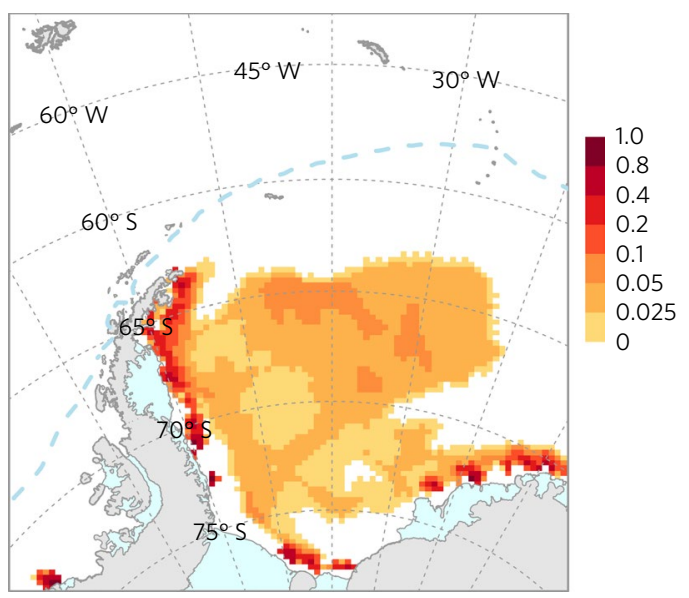

Fig. 6 | Winter krill habitat projections in the southwest Atlantic sector of the Southern Ocean. a,b, Sea-ice model output, showing favourable sea-ice habitats for larval krill in September under current conditions (a) and under a warm climate scenario (b). The colour scale indicates ridging rate (in \% per day) and the dashed blue line indicates the sea-ice extent. Ridging rate provides an indication of the degree of three-dimensional deformation of ice in the model; we use this as a proxy for habitat complexity.

Our investigations and previous studies demonstrate that larval krill exhibit an omnivorous feeding behaviour in winter ${ }^{14,15}$, suggesting that particulate organic matter might be a better proxy in the future to characterize food availability, especially in seasons when primary productivity is low.

The reverse diet vertical migration behaviour of the larvae observed is consistent with previous observations for late furcilia stages (stage IV onwards) ${ }^{1,22}$. Our foraging model results corroborate that this behaviour represents a beneficial adaptation for overwintering larvae to survive in a patchy food environment and to be transported to favourable feeding grounds in spring for rapid growth.

Our advection model results, showing where the new recruits will be located in the Scotia Sea in spring (Fig. 5c), are consistent with the high density of post-larval krill found north of the South Scotia Ridge in early summer and east of the South Sandwich Islands ${ }^{27-29}$ and reveal an important mechanism that sustains the high-density krill population in the Scotia Sea. The southern Scotia Sea region represents a favourable feeding ground in late winter-early spring (September-October) (Fig. 5d). Our results contribute to existing studies investigating the krill life cycle around Antarctica and/or transport mechanisms that support the highest krill biomass in East Antarctica ${ }^{30}$, western Antarctic Peninsula ${ }^{31}$ and Scotia Sea regions ${ }^{16}$.

Our findings imply that if, due to climate change, present habitats for larval krill overwintering and nursery in the South Scotia Ridge and southern Scotia Sea ${ }^{1}$ become ice free in winter, there may be an increase in food for larval krill development and growth ${ }^{32-37}$. If, however, the seasonal sea-ice cover does not extend as far north in future, then larvae that are released from under the sea ice in spring will be farther south in the Weddell Sea (south of the South Scotia Ridge in spring) and will take longer to reach the Scotia Sea ${ }^{17}$ (Supplementary Fig. 9).

Previous modelling studies focusing on the interaction between sea ice and the variability in krill biomass have demonstrated that autumn $^{11}$ and late winter-spring ${ }^{38}$ seem to be the bottlenecks for recruitment success in krill. Recently, a bioenergetic model demonstrated that the observed five to six year oscillation cycle between high and low krill biomass in the western Antarctic Peninsula depends on the food competition between larvae and adults in autumn ${ }^{12}$. Our findings support the view that seasons other than winter are the key to understanding krill recruitment. Combining our findings with previous model results ${ }^{11,12,38}$, we propose the following conceptual model. An early spawning in spring and favourable feeding conditions during summer enables larvae to develop to an advanced stage. An early sea-ice formation in autumn would separate larvae and adult krill, because association with sea ice decreases with krill age ${ }^{7}$ and larvae avoid food competition with the adults. However in winter, larval krill are very well adapted to cope with the food-poor winter conditions below the sea ice, outlined above. In late winter-early spring, the larvae require favourable feeding conditions to enable fast growth to post-larvae, to take advantage of spring-early summer blooms. Krill studies in autumn and late winter-early spring in key recruitment regions are therefore important for untangling the contribution of winter processes on the recruitment success and dynamics of the Southern Ocean key species, Antarctic krill E. superba.

\section{Methods}

General overview. We investigated feeding activity and growth rates of Antarctic krill larvae in the Scotia and northern Weddell Sea (14 August to 16 October 2013, Punta Arenas-Cape Town) in three different zones: (1) the persistently ice-free, open water (OW) region off South Georgia, (2) the marginal ice zone (MIZ) and (3) the pack-ice zone (PIZ). Food supply in terms of chl $a$ and particulate organic matter were measured in the water column and within sea ice as proxies for the autotrophic and heterotrophic/detrital biomass, respectively ${ }^{14,26,39}$. At all locations, larval krill sampling was performed with a number of different of net and pump systems.

Within the MIZ and PIZ, Terra-Synthetic Aperture Radar (TerraSAR) images and airborne electromagnetic (AEM)- measurements ${ }^{40}$ were used to locate areas of thin, less-deformed and thick, highly deformed sea-ice habitats. The difference between the mean and the modal sea-ice thickness indicates the degree of seaice deformation: the larger the difference, the higher the deformation of sea ice. This information was then related to the abundance of larvae determined by horizontal net tows and divers. In the PIZ, SCUBA divers performed intense under-ice surveys during the day and at night. Ice Camps 1 and 2 were occupied for 9 and 14 days, respectively, in highly ridged and rafted sea-ice regions. In addition, the divers made under-ice observations in less-deformed sea-ice regions, for example between Ice Camp 1 and 2 and in the MIZ. Concomitantly, during dive operations in the PIZ and MIZ, larval krill sampling at discrete depths was conducted from the RV Polarstern with a multinet. In addition, horizontal net tows with a rectangular midwater trawl, consisting of a $1 \mathrm{~m}^{2}$ and $8 \mathrm{~m}^{2}$ mouth area net (RMT 1+8) provided information on larval abundance over several kilometres and corroborated the data from the dive team.

Statistical analyses of data. Data were first tested for normality. If the data were not normally distributed, they were described by the medians with minimum and maximum values. Significant differences between normally distributed data were tested using a one-way analysis of variance. The Holm-Sidak post-hoc test was applied for multiple comparisons. All tests were performed using R version 3.1.2 $2^{41}$. The level of significance for all tests was set at $\alpha=0.05$. 
Larval krill sampling. Larval abundance on kilometre scales in open water, nonice-covered regions (OW) and different ice-covered habitats (MIZ and PIZ) was estimated by capture of krill in a rectangular midwater trawl, consisting of a $1 \mathrm{~m}^{2}$ and $8 \mathrm{~m}^{2}$ mouth area net $(\mathrm{RMT} 1+8)$. The RMT $1+8$, equipped with a real-time depth recorder and a General Oceanics flowmeter, was towed obliquely through the upper $500 \mathrm{~m}$ of the water column. Larval krill abundance was estimated from the amount of larvae caught by the $1 \mathrm{~m}^{2}$ net with $350 \mu \mathrm{m}$ mesh size.

For evaluating the condition of larvae in terms of feeding activity (indicated by the digestive gland size), growth rate and stomach content, larvae were sampled in the OW and the MIZ with a RMT or a Bongo net ${ }^{42}$, whereas in the PIZ, larvae were sampled by scientific divers using the plankton pump system MASMA (MAnguera SubMArina) ${ }^{9}$. MASMA consists of a motor-driven centrifugal pump filtering seawater through a zooplankton net with $200 \mu \mathrm{m}$ mesh size into a $21 \mathrm{cod}$ end, which was located inside an airtight container. Seawater was sucked through a tube with $0.055 \mathrm{~m}$ internal diameter and a maximum length of $50 \mathrm{~m}$ towards a pre-pump container $\left(0.1 \mathrm{~m}^{3} \mathrm{~min}^{-1}\right)$, where live undamaged larvae were collected. Two different MASMA systems were used, one stationary pump on an ice floe with a fixed flow rate of $0.1 \mathrm{~m}^{3} \mathrm{~min}^{-1}$, and the modular MASMA-Pro with an adjustable flow rate from $<0.04$ to $0.2 \mathrm{~m}^{3} \mathrm{~min}^{-1}$. The MASMA-Pro pump system is more flexible to use, making it more suitable for dive operations from ice floes or from a rubber boat and the adjustable flow rate enabled sampling of very delicate organisms, such as gelatinous species, to be collected in pristine physiological conditions. In addition, at Ice Camp 2, we collected larvae for stomach content analyses and ingestion rate measurements using the gut fluorescence method ${ }^{43}$. Larvae were sampled at different time intervals within a $24 \mathrm{~h}$ cycle with a fishpump (Aqualife Products, BP40) located onboard RV Polarstern. Seawater was pumped continuously $\left(54 \mathrm{~m}^{3} \mathrm{~h}^{-1}\right)$ through the ship's well-shaft onto a sieve from where the larvae were collected. All larvae used for stomach content analyses and ingestion rate measurements were immediately flash frozen in liquid nitrogen and stored at $-80{ }^{\circ} \mathrm{C}$.

Larval krill morphometrics, growth and stomach content analysis. Freshly caught furcilia stages (IV to VI) and young juveniles from the same year (Y0) were identified according to Fraser ${ }^{44}$ and summarized as larvae. Under a stereomicroscope, body length was measured from the anterior tip of the rostrum to the end of the telson, while carapace length $(\mathrm{CL})$ was measured from the anterior tip of the rostrum to the posterior notch of the carapace ${ }^{45}$. The size of the digestive gland (DG) was measured along its longest horizontal axis and its relative length in relation to the $\mathrm{CL}$ was calculated, as it provides information about the recent feeding activity of larvae $e^{46,47}$. Relative DG length $=(\mathrm{DG}$ length $(\mathrm{mm}) / \mathrm{CL}(\mathrm{mm})) \times 100$. Growth rates were measured following the instantaneous growth rate method for larvae ${ }^{48}$. In situ growth rates were determined by randomly sorting 100-400 freshly caught krill larvae and incubating the animals individually in $150 \mathrm{ml}$ jars with natural seawater at in situ sea surface temperature for three days. Animals were checked for moults twice daily. Moulted larvae and their moults were separated and measured with the following procedure using a Leica MZ 7.5 stereomicroscope and LAS Image Analysis software (http://www.leicamicrosystems.com/products/microscopesoftware/details/product/leica-las-X-ls). The daily moulting frequency and the growth increment on moulting defined as the $\%$ growth per intermoult-period $\left(\mathrm{IMP}^{-1}\right.$ ) was calculated according to Meyer et al. ${ }^{14}$ daily moulting frequency and the growth increment on moulting (\% growth $\mathrm{IMP}^{-1}$ ) was calculated according to Meyer et al. ${ }^{14}$. For stomach content analysis of larvae, 30 larval stomachs per region (OW, Ice Camp 1, Ice Camp 2, MIZ 2) were dissected on ice $^{14}$. Five stomachs were pooled in an Eppendorf vial and represent one sample. The total stomach fullness and content of each sample was estimated ${ }^{49}$ and the content identified ${ }^{50}$

SCUBA dive operations. A total of 68 dives were undertaken under the sea ice at four locations. Three different diver-based observation methods were employed to assess the spatiotemporal distribution of larval krill associated with the under-ice habitat: video-assisted reconnaissance, fixed video transects and photo quadrants. Methods similar to those commonly used in the assessment of demersal fauna in temperate and tropical reefs ${ }^{51}$ were adopted and adjusted for under-ice conditions. Operations were limited to a maximum distance of $50 \mathrm{~m}$ from the main entry point to the security holes determined by the maximum length of the safety line that contained the communications system and connected the divers to the point of entry (Supplementary Fig. 10a). Reconnaissance dives were undertaken to obtain a general impression of the under-ice landscape around the entry point and to investigate the general distribution and behaviour of krill larvae under the ice. Video footage was taken using a Sony HDR-CX 740 VE camera system in an underwater housing and subsequently analysed. For the video transects, polypropylene ropes were fixed to ice screws attached to the diver entry hole and spanned to the security ice holes such that they formed straight lines on the under-ice surface, leading away in different directions from the main entry hole. The rope was marked every $5 \mathrm{~m}$ with yellow tape. Under-ice profiles were characterized at every $5 \mathrm{~m}$ transect by three depth categories (high: $>2 \mathrm{~m}$; medium: 1-2 m; low: <1 m difference in elevation) and two surface roughness categories (high: surface uneven; low: surface even). The diver moved along the rope away from the entry hole at constant depth and filmed such that the transect line formed the vertical mid-line of the video frame and the ice horizon was in line with the frame's lower border. To maintain consistency of the filmed area among dives, the underwater camera was clipped into the fixed transect line with a $0.5 \mathrm{~m}$ lead line. Video transects were customarily carried out on all transect lines during one single dive. Transects were monitored around midday, in the late afternoon and at night. Two spotlights attached to the camera were used to illuminate the transect area at night. The total number of krill per $5 \mathrm{~m}$ section was then determined during video analyses. For performing the photo quadrants, a metal rod was attached to the housing of an underwater camera (Supplementary Fig. 10b) such that the area of an image taken of the under-ice surface (measured $0.159 \mathrm{~m}^{2}$ ) was equal on each photo when taken with the rod in a right angle to the ice surface and the tip of the rod touching the ice. A diver took 30 random pictures of the ice surface within a maximum distance of $25 \mathrm{~m}$ from the entry hole. The angle of the under-ice surface was recorded in three categories (ceiling, vertical wall and terrace). The number of krill larvae visible on each image was then counted (Supplementary Fig. 10c).

Statistical analyses of dive operations. A randomization test was used to ascertain the independence of adjacent sections of the video transects. The similarity between counts of adjacent sections as a possible sign of spatial autocorrelation was hereby compared with that of the same number of randomly selected sections. The two samples (sets of absolute differences between pairs of sections, adjacent and random) were tested for significant differences (Mann-Whitney $U$-test). A similar procedure was used to determine preference or avoidance of transect sections during consecutive days. Here the transect sections were ranked according to larval krill counts. The sum of the absolute differences between ranks for consecutive days was established for each transect section, summed and compared with that of randomly drawn ranks.

Non-parametric statistics (Mann-Whitney $U$-test, Kruskal-Wallis test) were employed to test effects of under-ice profile and surface roughness as well as differences in larval krill abundance measured as total number of krill larvae per transect section between day and night, midday and afternoon, and among consecutive days. Abundance of larval krill attached to the ice, measured as number of larvae per photo frame, was tested against under-ice surface orientation (Kruskal-Wallis test). All tests were carried out in the statistical software $\mathrm{R}^{41}$.

Krill in the photo quadrants had a very patchy distribution, with a large number of zero counts and few very large numbers. Consequently, a nonparametric bootstrap procedure was conducted to obtain $95 \%$ confidence intervals for estimates of mean abundance ${ }^{52}$. Hereby, data were sampled with a replacement 1,000 times and the mean was calculated for each sample. The percentile method by Buckland ${ }^{53}$ was used to estimate $95 \%$ confidence intervals from the resulting bootstrap vectors, where the 2.5 th and 97.5 th percentiles were chosen to obtain the lower and upper $95 \%$ confidence intervals, respectively.

Conceptual foraging model. Description of the vertical migration foraging model following the overview, design concepts and details protocol (ODD protocol) ${ }^{54}$. Submodels are presented in the Supplementary information in full detail.

The purpose of this model was to investigate how much food a group of krill larvae can collect depending on their movement strategy and the spatial distribution of food. This is a first step to understand the evolutionary consequences of the distinct daily vertical migration patterns determined by larval krill in our study.

Entities, state variables and scales: a group of krill larvae is modelled as a super individual, that is, the group is regarded as an entity, which makes collective decisions. The krill larvae super individual has food uptake as a state variable.

The environment consists of $180 \times 180$ patches (grid cells). Each patch is either empty (black) or contains food (green). The spatial extent of one patch is arbitrary and defined by the area that can be completely grazed in one time step (one day). The simulation arena has closed boundaries, that is, individuals have to stop at the edges. After initialization, the krill larvae super individual moves and forages for 60 time steps. The model represents different spatial distributions of the food resource (clustered versus homogeneous). The spatial configuration of the food patches has a stochastic element, that is, the centres of clusters are distributed randomly in space. Also the movement of the krill school has a stochastic element. Depending on the movement rules and the number of clusters, the characteristic frequency distribution of the food patches found emerges from repetitions of the simulation. The school of krill larvae is modelled collectively as a super individual. Sensing of food of the super individual is restricted to its present patch. For the simulation experiments, it is assumed that $10 \%$ of all patches contain food at the beginning of the simulation. There are two scenarios for how food is distributed in the simulation arena: (1) complete random distribution of food representing the situation in the open water and (2) food patches are aggregated in ten clusters that have all the same size, if possible. As the centres of clusters are randomly located, it can happen that clusters overlap. Nevertheless, the initialization of clusters is implemented in a way that, even if clusters overlap, $10 \%$ of all patches are food patches. Shapes of the clusters approximate circles (Supplementary Fig. 11a). The super individual is located at the centre of the left edge of the arena facing directly to the opposite edge (Supplementary Fig. 11b). The model does not include any input of external data describing environmental variables. 
Advection model. To identify likely source regions and the subsequent transport of larval krill observed during the ice camp studies, we used a second-order Runge-Kutta advection model that incorporated a simple parameterization of the vertical migration behaviour of the larval krill. Explicit diffusion was not included. The time step of the model was two hours, meeting local stability criteria. Sea-ice-ocean models of this region struggle to accurately represent the seasonal sea-ice cycle ${ }^{55}$, and thus the advection model used remotely sensed data for the velocity fields. These comprised daily fields of near-surface ocean current data (delayed time mean absolute dynamic topography distributed by Aviso), which provide a measure of the mesoscale geostrophic component of flow and sea-ice motion $^{56}$. Vertical current shear is not included in the model; as such, we assume that larvae are transported in the near-surface layer of the ocean, which matches the observations of vertical larval distribution from this survey. The sea-ice motion velocity data were scaled by a factor of 1.53 (ref. ${ }^{57}$ ) and mapped from an original horizontal resolution of $25 \mathrm{~km}$ onto the horizontal Cartesian grid $\left(1 / 4^{\circ}\right)$ of the ocean current data prior to use in the advection model. Because sea-ice cover prevents the estimation of altimetry-derived ocean currents, under-ice ocean currents were estimated from the sea-ice motion data, scaling the magnitude of the velocity components by 0.43 and applying an offset of $-35^{\circ}$ to the sea-ice motion direction ${ }^{58,59}$. This simplified, fixed relationship gives an indication of the main direction of flow beneath the ice at the regional scale that we are interested in for this study. At smaller scales, the variability in the under-ice currents compared with the sea-ice motion will have an impact on local transport and retention. Comparison of the derived fields with vessel-mounted acoustic Doppler current profiler measurements taken during the survey showed that the derived under-ice speeds were in the same range as the observations.

To examine the impact of larval behaviour on transport, a vertical migration scheme was used in the model in which the simulated larvae followed one of two behaviour strategies when in areas of sea-ice cover: (1) larvae were subject to a daily migration cycle spending 12 hours per day moving with the sea ice and 12 hours moving beneath the sea ice with the derived under-ice ocean currents; (2) larvae were assumed to have no association with the sea ice and were advected with the derived under-ice ocean currents only (Supplementary Fig. 9). Once away from sea-ice cover, all larvae were advected with the near-surface ocean velocity fields. We assumed that the larval krill observed in the present study must overwinter under sea ice ${ }^{1}$. Thus, larvae were released in the model from each grid cell with sea-ice cover in late autumn (1 April; one larva per grid cell) and transport was simulated until November of the same year. Locations from which larvae reached the South Scotia Ridge in mid-September (the time of the survey) were identified. The model was run for nine years (2005-2013) to investigate interannual variability in the predicted trajectories. Due to interannual variability in sea-ice extent, the total number of modelled larvae varied each year. Timing of sea-ice advance along the western Antarctic Peninsula is such that there were no under-ice locations in April that resulted in transport to the South Scotia Ridge by the following September and so all larval release cells were located in the Weddell Sea. The overall pattern of results was not sensitive to changing the release date of the larvae by \pm 1 week. The temporal and spatial resolution of the velocity fields used in the model mean that high-frequency variability is not represented in these simulations, and instead we use the model to investigate regional-scale patterns of transport.

\section{Identification of larval krill habitat from sea-ice model output under present} and future scenarios. A sea-ice model output was derived from an 11 year (1998-2008) numerical simulation of Southern Ocean sea ice, conducted using the Los Alamos sea-ice model (CICE4 4$)^{60}$ configured in stand-alone mode on a quarterdegree grid. A single-year warm climate scenario approximating conditions for 2100 was also undertaken; the conditions for this scenario were consistent with projected changes for the Southern Ocean described in the Fourth Assessment Report from the Intergovernmental Panel on Climate Change ${ }^{19}$. Specifically, the following changes were applied uniformly to the present climate forcing field for a single year: a $2{ }^{\circ} \mathrm{C}$ increase in air temperature, a $0.2 \mathrm{~mm} \mathrm{~d}^{-1}$ increase in precipitation, a $1.5 \%$ increase in cloud fraction, a $-2.3 \mathrm{hPa}$ change in surface air pressure, a $25 \%$ increase in wind, a $12 \mathrm{Wm}^{-2}$ increase in longwave downward radiation and a $20 \%$ increase in humidity.

Sea-ice model to determine larval krill habitat. To identify areas of suitable larval krill habitat in September under present conditions and the warm climate scenario, we adapted the methodology of Melbourne-Thomas et al. ${ }^{18}$ to match mapped variables identified as important habitat features in the main text (ice thickness between 1 and $2 \mathrm{~m}$, three-dimensional complexity and 60-70\% ice concentration). As such, suitable habitat was identified in the model output by selecting areas between 1 and $2 \mathrm{~m}$ sea-ice thickness and examining spatial patterns of habitat complexity (ridging rate) and sea-ice concentration (at a quarter-degree scale and based on monthly means of each sea-ice model variable) within this area.

Life Sciences Reporting Summary. Further information on experimental design and reagents is available in the Life Sciences Reporting Summary.

Data availability. The data presented in this paper are available at https://doi org/10.1594/PANGAEA.864710.
Received: 22 January 2017; Accepted: 22 September 2017; Published online: 13 November 2017

\section{References}

1. Marr, J. W. S. The natural history and geography of the Antarctic krill (Euphausia superba Dana). Discovery Rep. 32, 33-464 (1962).

2. Croxall, J. P., Reid, K. \& Prince, P. A. Diet, provisioning and productivity responses of marine predators to differences in availability of Antarctic krill. Mar. Ecol. Prog. Ser. 177, 115-131 (1999).

3. Atkinson, A., Siegel, V., Pakhomov, E. \& Rothery, P. Long-term decline in krill stock and increase in salps within the Southern Ocean. Nature 432, 100-103 (2004)

4. Loeb, V. et al. Effects of sea-ice extent and krill or salp dominance on the Antarctic food web. Nature 387, 897-900 (1997).

5. Siegel, V. Distribution and population dynamics of Euphausia superba: summary of recent findings. Polar Biol. 29, 1-22 (2005).

6. Quetin, L. B. et al. Growth of larval krill, Euphausia superba, in fall and winter west of the Antarctic Peninsula. Mar. Biol. 143, 833-843 (2003).

7. Quetin, L. B., Ross, R. M., Fritsen, C. H. \& Vernet, M. Ecological responses of Antarctic krill to environmental variability: can we predict the future? Antarct. Sci. 19, 253-266 (2007).

8. Ross, R. M., Quetin, L. B., Newberger, T. \& Oakes, S. A. Growth and behaviour of larval krill (Euphausia superba) under the ice in late winter 2001 west of the Antarctic Peninsula. Deep-Sea Res. Pt II 51, 2169-2184 (2004).

9. Ross, R. M. et al. Trends, cycles, interannual variability for three pelagic species west of the Antarctic Peninsula 1993-2008. Mar. Ecol. Prog. Ser. 515, 11-32 (2014).

10. Reiss, C. S. et al. Overwinter habitat selection by Antarctic krill under varying sea-ice conditions: implications for top predators and fishery management. Mar. Ecol. Prog. Ser. 568, 1-16 (2017).

11. Lowe, A. T., Ross, R. M., Quetin, L. B., Vernet, M. \& Fritsen, C. H. Simulating larval Antarctic krill growth and condition factor during fall and winter in response to environmental variability. Mar. Ecol. Prog. Ser. 452, 27-43 (2012).

12. Ryabov, A. B., de Roos, A. M., Meyer, B., Kawaguchi, S. \& Blasius, B. Competition-induced starvation drives large-scale population cycles in Antarctic krill. Nat. Ecol. Evol. 1, 0177 (2017).

13. Fritsen, C. H., Memmott, J. \& Stewart, F. J. Inter-annual sea-ice dynamics and micro-algal biomass in winter pack ice of Marguerite Bay, Antarctica. Deep-Sea Res. Pt II 55, 2059-2067 (2008).

14. Meyer, B. et al. Physiology, growth and development of larval krill Euphausia superba in autumn and winter in the Lazarev Sea, Antarctica. Limnol. Oceanogr. 54, 1595-1614 (2009).

15. Daly, K. L. Overwintering growth and development of larval Euphausia superba: an interannual comparison under varying environmental conditions west of the Antarctic Peninsula. Deep-Sea Res. Pt II 51, 2139-2168 (2004).

16. Murphy, E. J. et al. Spatial and temporal operation of the Scotia Sea ecosystem: a review of large-scale links in a krill centered food web. Phil. Trans. R. Soc. B 362, 113-148 (2007).

17. Thorpe, S. E., Murphy, E. J. \& Watkins, J. L. Circumpolar connections between Antarctic krill (Euphausia superba Dana) populations: investigating the roles of ocean and sea ice transport. Deep-Sea Res. Pt I 54, 792-810 (2007).

18. Melbourne-Thomas, J. et al. Under-ice habitats for Antarctic krill larvae: could less mean more under climate warming? Geophys. Res. Lett. 43, 10322-10327 (2016).

19. Meehl G. et al. in Climate Change 2007: The Physical Science Basis (eds Solomon, S. et al.) Ch. 10 (Cambridge Univ. Press, Cambridge, 2007).

20. Meyer, B. The overwintering of Antarctic krill, Euphausia superba, from an ecophysiological perspective. A Review. Polar Biol. 35, 15-37 (2012).

21. Frazer, T. K., Quetin, L. B. \& Ross, R. M. Abundance, size and developmental stages of larval krill, Euphausia superba, during winter in ice-covered seas west of the Antarctic Peninsula. J. Plank. Res. 24, 1067-1077 (2002).

22. Quetin, L. B., Ross, R. M., Frazer, T. K. \& Haberman, K. I. Factors affecting distribution and abundance of zooplankton, with an emphasis on Antarctic krill Euphausia superba. Antarct. Res. Ser. 70, 357-371 (1996).

23. Heywood, R. B., Everson, I. \& Priddle, J. The absence of krill from the South Georgia zone, winter 1983. Deep-Sea Res. 32, 369-378 (1985).

24. Morris, D. J. \& Priddle, J. Observation on the feeding and moulting of the Antarctic krill, Euphausia superba Dana, in winter. Brit. Antarct. Surv. Bull. 65, 57-63 (1984).

25. Marra, J. \& Boardman, C. Late winter chlorophyll $a$ distribution in the Weddell Sea. Mar. Ecol. Prog. Ser. 19, 197-208 (1984).

26. Meiners, K. M. et al. Chlorophyll $a$ in Antarctic sea ice from historical ice core data. Geophys. Res. Lett. 39, L21602 (2012).

27. Atkinson, A. et al. Oceanic circumpolar habitats of Antarctic krill. Mar. Ecol. Prog. Ser. 362, 1-23 (2008). 
28. Hewitt, R. P. et al. Variation in the biomass density and demography of Antarctic krill in the vicinity of the South Shetland Islands during the 1999/2000 austral summer. Deep-Sea Res. Pt II 51, 1411-1419 (2004).

29. Siegel, V. et al. Krill demography and large-scale distribution in the southwest Atlantic during January/February 2000. Deep-Sea Res. Pt II 51, 1253-1273 (2004)

30. Nicol, S. et al. Ocean circulation off east Antarctica affects structure and sea-ice extent. Nature 406, 204-507 (2000)

31. Piñones, A., Hoffmann, E. E., Daly, K. L. \& Dinniman, S. Modeling environmental controls on the transport and fate of early life stages of Antarctic krill (Euphausia superba) on the western Antarctic Peninsula continental shelf. Deep-Sea Res. Pt I 82, 17-31 (2013).

32. Montes-Hugo, M. et al. Recent changes in phytoplankton communities associated with rapid regional climate change along the western Antarctic Peninsula. Science 323, 1470-1473 (2009).

33. Bopp, L. et al. Multiple stressors of ocean ecosystems in the 21st century: projections with CMIP5 models. Biogeosciences 10, 6225-6245 (2013)

34. Rose, J. M. et al. Synergistic effects of iron and temperature on Antarctic phytoplankton and microzooplankton assemblages. Biogeosciences $\mathbf{6}$ 3131-3147 (2009).

35. Hoppema, M. et al. Whole season net community production in the Weddell Sea. Polar Biol. 31, 101-111 (2007).

36. Arrigo, K. R., van Dijken, G. L. \& Bushinsky, S. Primary production in the Southern Ocean, 1997-2006. J. Geophys. Res. 113, C08004 (2008).

37. de Jong, J. et al. Natural iron fertilization of the Atlantic sector of the Southern Ocean by continental shelf sources of the Antarctic Peninsula. J. Geophys. Res. 117, G01029 (2012).

38. Wiedenmann, J., Cresswell, K. A. \& Mangel, M. Connecting recruitment of Antarctic krill and sea ice. Limnol. Oceanogr. 54, 799-811 (2009).

39. Knap, A., Michaels, A., Close, A., Ducklow, H. \& Dickson, A. Measurement of chlorophyll $a$ and phaeopigments by fluorometric analysis. JGOFS Rep. 19, 118-122 (1996).

40. Haas, C., Lobach, J., Hendricks, S., Rabenstein, L. \& Pfaffling, A. Helicopterborne measurements of sea ice thickness, using a small and lightweight, digital EM system. J. Appl. Geophys. 67, 234-241 (2009).

41. R Core Team R: A Language and Environment for Statistical Computing (R Foundation for Statistical Computing, Vienna, 2014); http://www.R-project.org/

42. Meyer, B., Atkinson, A., Blume, B. \& Bathmann, U. V. Feeding and energy budgets of larval Antarctic krill Euphausia superba in summer. Mar. Ecol. Prog. Ser. 257, 167-178 (2003).

43. Pakhomov, E. A., Atkinson, A., Meyer, B., Oettl, B. \& Bathmann, U. Daily rations and growth of larval Euphausia superba in the Eastern Bellingshausen Sea during austral autumn. Deep-Sea Res. Pt II 51, 2185-2198 (2004).

44. Fraser, F. C. On the development and distribution of young stages of krill (Euphausia superba). Discovery Rep. 24, 1-192 (1936).

45. Meyer, B. et al. Seasonal variation in body composition, metabolic activity, feeding, and growth of adult krill Euphausia superba in the Lazarev Sea. Mar. Ecol. Prog. Ser. 398, 1-18 (2010).

46. Nicol, S. et al. Condition of Euphausia crystallorophias off East Antarctica in winter in comparison to other seasons. Deep-Sea Res. Pt II 51, 2215-2224 (2004)

47. O’Brien, C., Virtue, P., Kawaguchi, S. \& Nichols, P. D. Aspects of krill growth and condition during late winter-early spring of East Antarctica $\left(110-130^{\circ} \mathrm{E}\right)$. Deep-Sea Res. Pt II 58, 1211-1221 (2010).

48. Quetin, L. B. \& Ross, R. M. Behavioural and physiological characteristics of the Antarctic krill Euphausia superba. Am. Zool. 31, 49-63 (1991).

49. Gradinger, R. \& Bluhm, B. Timing of ice algal grazing by the Arctic nearshore benthic amphipod Onisimus litoralis. Arctic 63, 355-358 (2010).

50. Scott, F. J. \& Marchant, H. Antarctic Marine Protists (Australian Antarctic Division, Hobart Australian Biological Resources Study, Canberra, 2005).

51. Thresher, R. E. \& Gunn, J. S. Comparative analysis of visual census techniques for highly mobile, reef-associated piscivores (Carangidae). Environ. Biol. Fish. 17, 93-116 (1986).

52. Efron, B. \& Tibshirani, R. Bootstrap methods for standard errors, confidence intervals, and other measures of statistical accuracy. Statist. Sci. 1, 54-77 (1986)
53. Buckland, S. T. Monte-Carlo confidence intervals. Biometrics 40, 811-817 (1984).

54. Grimm, V. et al. The ODD protocol: a review and first update. Ecol. Model. 221, 2760-2768 (2010).

55. Renner, A. H. H., Heywood, K. J. \& Thorpe, S. E. Validation of three global ocean models in the Weddell Sea. Ocean Model. 30, 1-15 (2009).

56. Tschudi, M., Fowler, C., Maslanik, J., Stewart, J. S. \& Meier, W. Polar Pathfinder Daily $25 \mathrm{~km}$ EASE-Grid Sea Ice Motion Vectors, Version 3 (National Snow and Ice Data Center, Boulder, CO, 2013); https://doi. org/10.5067/O57VAIT2AYYY

57. Schwegmann, S., Haas, C., Fowler, C. \& Gerdes, R. A. Comparison of satellite-derived sea-ice motion with drifting-buoy data in the Weddell Sea, Antarctica. Ann. Glaciol. 52, 103-110 (2011).

58. McPhee, M. G. \& Martinson, D. G. Turbulent mixing under drifting pack ice in the Weddell Sea. Science 263, 218-221 (1994).

59. Cole, S. T., Timmermans, M. L., Toole, J. M., Krishfield, R. A. \& Thwaites, F T. Ekman veering, internal waves, and turbulence observed under Arctic sea ice. J. Phys. Oceanogr. 44, 1306-1328 (2014).

60. Bailey, D. et al. Community Ice CodE (CICE) User's Guide Version 4.0 (National Center for Atmospheric Research, 2010).

\section{Acknowledgements}

We thank the captain and crew of RV Polarstern expedition WISKY (ANTXXIX-7) as well as our helicopter teams for their excellent support with work at sea, R. Schlicht for statistical consultation and B. Raymond for technical contribution to present results. This work was funded by the PACES (Polar Regions and Coasts in a changing Earth System) programme (Topic 1, WP 5) of the Helmholtz Association. Additional funds were made available via the Helmholtz Virtual Institute 'PolarTime' (VH-VI-500: Biological timing in a changing marine environment-clocks and rhythms in polar pelagic organisms) and the Australian Government through Antarctic Science grant \#4073 and the Antarctic Climate and Ecosystem Cooperative Research Centre. S.E.T. and E.J.M. were funded by the Natural Environment Research Council under British Antarctic Survey National Capability-Ecosystems. The surface velocity data were produced by Ssalto/Duacs and distributed by Aviso, with support from Cnes (http://www.aviso.altimetry.fr/duacs/). TerraSAR-X images used to identify sampling sites were provided by German Space Agency (DLR) via the proposal "Investigation of the role of sea ice and snow properties on Antarctic krill distribution and condition in winter/spring". We thank T. Busche (DLR) and E. Schwarz (DLR) for organizing near-real time image delivery on board of Polarstern.

\section{Author contributions}

B.M. and U.F. designed the research and B.M. wrote the paper with support from the co-authors. U.F., S.K. and A.G. designed the scientific dive operations with support from I.N.Y., G.N., M.T. and L.A. Ice physical investigations were performed by T.K., R.R., K.M.M. and S.S. The foraging model was designed by J.G. with support from V.G. S.E.T. and E.J.M. worked on the advection model, whereas J.M.-T., R.T., M.S., S.K. and K.M.M. performed the sea-ice model. Larval krill morphology, physiology and abundance data were collected and processed by R.K., L.H., E.P., B.P.V.H., M.T., S.J. and B.M. Sea-ice biology data were collected and analysed by L.H., B.M. and K.M.M. The climatology and water column data were collected and processed by C.K. and D.W.-G.

\section{Competing interests}

The authors declare no competing financial interests.

\section{Additional information}

Supplementary information is available for this paper at https://doi.org/10.1038/ s41559-017-0368-3.

Reprints and permissions information is available at www.nature.com/reprints. Correspondence and requests for materials should be addressed to B.M.

Publisher's note: Springer Nature remains neutral with regard to jurisdictional claims in published maps and institutional affiliations. 


\section{natureresearch}

Corresponding author(s): Bettina Meyer

$\square$ Initial submission $\square$ Revised version $\quad$ Final submission

\section{Life Sciences Reporting Summary}

Nature Research wishes to improve the reproducibility of the work that we publish. This form is intended for publication with all accepted life science papers and provides structure for consistency and transparency in reporting. Every life science submission will use this form; some list items might not apply to an individual manuscript, but all fields must be completed for clarity.

For further information on the points included in this form, see Reporting Life Sciences Research. For further information on Nature Research policies, including our data availability policy, see Authors \& Referees and the Editorial Policy Checklist.

\section{- Experimental design}

\section{Sample size}

Describe how sample size was determined.

2. Data exclusions

Describe any data exclusions.

\section{Replication}

Describe whether the experimental findings were reliably reproduced.

\section{Randomization}

Describe how samples/organisms/participants were allocated into experimental groups.

5. Blinding

Describe whether the investigators were blinded to group allocation during data collection and/or analysis.
In accordance to the current knowledge in our research field

No samples were excluded

The experimental findings were reliable reproduced, indicated by the number of replicates documented.

Freshly caught animals were always randomly selected from our sampling gear for further analytical procedures

We did not used this procedure

Note: all studies involving animals and/or human research participants must disclose whether blinding and randomization were used.

\section{Statistical parameters}

For all figures and tables that use statistical methods, confirm that the following items are present in relevant figure legends (or in the Methods section if additional space is needed).

n/a $\mid$ Confirmed

\The exact sample size $(n)$ for each experimental group/condition, given as a discrete number and unit of measurement (animals, litters, cultures, etc.)

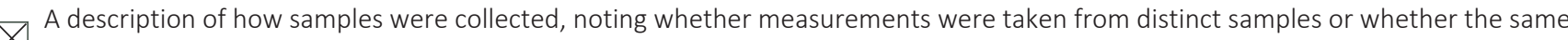
sample was measured repeatedly

\ A statement indicating how many times each experiment was replicated

The statistical test(s) used and whether they are one- or two-sided (note: only common tests should be described solely by name; more complex techniques should be described in the Methods section)

$\bigotimes$ A description of any assumptions or corrections, such as an adjustment for multiple comparisons

$\square \bigotimes$ The test results (e.g. $P$ values) given as exact values whenever possible and with confidence intervals noted

$\square \bigotimes$ A clear description of statistics including central tendency (e.g. median, mean) and variation (e.g. standard deviation, interquartile range)

$\square$ \Clearly defined error bars 
Policy information about availability of computer code

\section{Software}

Describe the software used to analyze the data in this study.

For manuscripts utilizing custom algorithms or software that are central to the paper but not yet described in the published literature, software must be made available to editors and reviewers upon request. We strongly encourage code deposition in a community repository (e.g. GitHub). Nature Methods guidance for providing algorithms and software for publication provides further information on this topic.

\section{- Materials and reagents}

Policy information about availability of materials

\section{Materials availability}

Indicate whether there are restrictions on availability of unique materials or if these materials are only available for distribution by a for-profit company.

\section{Antibodies}

Describe the antibodies used and how they were validated for use in the system under study (i.e. assay and species).

10. Eukaryotic cell lines

a. State the source of each eukaryotic cell line used.

b. Describe the method of cell line authentication used.

c. Report whether the cell lines were tested for mycoplasma contamination.

d. If any of the cell lines used are listed in the database of commonly misidentified cell lines maintained by ICLAC, provide a scientific rationale for their use.

\section{$\mathrm{n} / \mathrm{a}$}

\section{$\mathrm{n} / \mathrm{a}$}

$n / n / a$

\section{- Animals and human research participants}

Policy information about studies involving animals; when reporting animal research, follow the ARRIVE guidelines

\section{Description of research animals}

Provide details on animals and/or animal-derived materials used in the study. $n / a$

Policy information about studies involving human research participants

\section{Description of human research participants}

Describe the covariate-relevant population characteristics of the human research participants. $n / a$ 